\title{
INTERPRETING THE STORY OF THE SHIPWRECKED SAILOR ${ }^{1}$
}

\author{
By JOHN BAINES
}

\begin{abstract}
The story of the Shipwrecked Sailor is a complex work of written literature that is based partly on esoteric knowledge. Its superficial presentation looks to folk and oral models in style, situation, anonymity, and treatment of character, making play with traditional and proverbial wisdom. It is not allegorical in any simple sense. The conception of the seventy-four forms of the sun god is encapsulated within the folk/oral treatment, while the deviant wisdom that offerings to the gods are pointless is relativized by being put forward by a god. The core narrative of the end of things is a myth that is linked to moralizing on a modest, domestic scale; this pairing has parallels in religious texts. All these meanings are organized within a cyclical form which exploits first-person narration for ironical effect. The text is not didactic in a straightforward way, but has the unifying theme of experience and how it is confronted.
\end{abstract}

THE conventional interpretation of the Shipwrecked Sailor has changed slowly from a view of the text as a simple folk story ${ }^{2}$ to one of a complex, many-layered narrative in which the traveller moves in space and time to the limit of the cosmos, to a mythical place where he encounters a primordial god who relates to him a moralized vision of the end of

\footnotetext{
${ }^{1}$ Referred to in the notes as ShS, and in the text by line numbers. Original edition with photographs: W. Golénischeff, Les papyrus hiératiques $N^{o} N^{o} 1115,1116$ A et ${ }_{111} 6 \mathrm{~B}$ de l'Ermitage Impérial de $S^{t}$-Pétersbourg ([St Petersburg J, I913), I-3, pls. i-viii, 1-8. Standard text: A. M. Blackman, Middle-Egyptian Stories (Brussels, 1932), $4^{r-8}$ (the hieratic transcription could be improved on a few minor points). Translated quotations display metrical colon and 'line' divisions by means of spaces and ' $\%$ '. In very many cases the latter agree with J. L. Foster, $S A K$ i 5 ( 988 ), $93^{-7}$.

Selective bibliography of text, translations and studies: W. K. Simpson, $L A \ddot{v}, 619^{-22}$. Studies not listed there or appearing later include: J.-L. Chappaz, 'Que diable allaient-ils faire dans cette galère? Recherche sur le thême de la navigation dans quelques contes égyptiens', BSEG 3 (r980), 3-7; E. N. Maksimov, 'O vzaimodeistvii religii $\mathrm{i}$ fol'klora na primere obraza volshebnogo zmeya iz "Skazki o poterpevshem korablekrushenie" " On the interaction of religion and folklore, from the example of the magic snake in the 'Story of the Shipwrecked Sailor'], in Drevnii Vostok, Sbornik 2, Ak. Nauk SSSR (Moscow, 1980), $120-6$ (French abstract p. 2 I 2); A. Spalinger, 'An Alarming Parallel to the end of the Shipwrecked Sailor', $G M 73$ (1 984), 91-5 (with bibliography); S. Donadoni, 'Il naufragio del "Naufrago"', BSEG 9-1 o (1 984-5), 87-8; D. Kurth, 'Zur Interpretation der Geschichte des Schiffbrüchigen', $S A K$ I4 (I987), I67-79; B. Radomska, 'Die Insel des Schiffbrüchigen-eine Halbinsel?', $G M 99$ (1987), 27-30; D. Devauchelle, 'Naufragé 184- I 86', GM I I ( 1988 ), 2 1-5; J. L. Foster, "'The Shipwrecked Sailor": Prose or Verse? (Postponing Clauses or Tenseneutral Clauses)', $S A K$ i 5,69 - I 09 .

Eberhard Otto's 'Die Geschichten des Sinuhe und des Schiffbrüchigen als "lehrhafte Stücke"', ZÄS 93 ( 1966 ), $100^{-1} 1$, is particularly valuable. I see the text as less didactic than he did.

I should like to thank J. C. A. Baines and David Silverman for advice and help. Christopher Eyre and Richard Parkinson made valuable comments on a draft, emphasizing how rich the text's implications are and how many approaches to it are possible; I do not indicate separately the points I owe to them. I am grateful to the University of Arizona, the Alexander von Humboldt-Stiftung and the University of Münster for facilities granted during work on the text.

${ }^{2}$ See Kurth, $S A K$ I $4,167-8$, citations I-4; still maintained, for example, by D. B. Redford, $7 S S E A 6$ (1 975), 13-16. The parallel description of Red Sea snakes, which Redford cites from Philostratus' Life of Apollonius of Tyana, is apt, but it does not exhaust the text's meaning.
} 
the cosmos, and then returns to Egypt. ${ }^{3}$ The newer reading does much more justice to the text's meaning, but it has been achieved at the expense of some of the awareness of superficial form implicit in its predecessor, and of what the text itself says or implies about its meaning. ${ }^{4}$ It is worth returning to the text to consider its form and associations, and to incorporate additional approaches in order to enhance comprehension of it as a literary whole. If the story is seen as a unity, it should nevertheless be asked whether its meaning is unitary, and whether the various strands point in the same direction or should not be reconciled. Such questions assume that the text is a self-conscious work of literature and not a 'naive' product whose features might be the result of chance.

This point, which seems to be accepted by almost all who have written recently about the text (see n.2), has important theoretical implications, but these do not need to be pursued here, because, although my discussion implies and exploits the concept of a single author, it aims not to recreate that author's intention but to model meanings available to a modern, and ideally an ancient, audience. ${ }^{5}$ In part, it builds on suggestions that some bodies of Egyptian texts and knowledge were exclusive or esoteric.

It is necessary to relate the text to a hypothetical milieu from which its written form may have sprung. Because only one manuscript is known and nothing closely comparable is preserved, ${ }^{6}$ interpretation must depend heavily on the reading of the text itself and on thematic or cultural analogies, some of them remote. For the latter exercise, even a unique work can be set in a partly hypothetical context of other literary creations and of non-written practices; interpretations with such a basis may be disproved, but they are potentially more revealing than ones that do not make similar assumptions. ${ }^{7}$ What is almost lacking is an indication of how the Egyptians themselves received the text. Here, evidence could come from multiple copies, from the later development of its genre, or from verbal or other allusions, but there is scant trace of such responses. ${ }^{8}$ This assessment may be modified by new evidence, but, in comparison with instruction texts in particular, the Shipwrecked Sailor does not form part of a large genre.

\footnotetext{
${ }^{3}$ The first author to propose this reading, which has been elaborated by others, was G. Lanczkowski, $Z D M G$ I03 (1953), 360-7 I. His 'Parallelmotive zu einer altägyptischen Erzählung', $Z D M G$ I 05 (1955), $239^{-60}$, in which he related the core of the text to Ethiopian religion, seems to me mistaken in method and conclusions. See also $n$. 7 below.

${ }^{+}$The chief author to explore the latter aspect was Otto, ZZ̈S 93, Ioo-I I. B. M. Bryan, Sarapis 5 (I979), $3^{-1} 3$, follows a similar strategy. See also Kurth, $S A K$ I 4 , esp. I 77 no. 2.

5 This formulation does not do justice to problems of literary intentionality, and in particular ignores issues raised by E. D. Hirsch, Validity in Interpretation (New Haven and London, 1967); these are tangential here and would need separate discussion.

"The text that is nearest in general character is the brief Herdsman's Story, preserved at the end of the manuscript of the Dispute of a Man with his Ba: A. H. Gardiner, Die Erzählung des Sinuhe und die Hirtengeschichte (Leipzig, I go9), pls. I6-I 7; R. Drenkhahn, LÄ II, I 223-4; fullest study H. Goedicke, $C d E 45$ ( 1970 ), $244^{-66}$. See also n. 73 below.

${ }^{7}$ Kurth, $S A K$ 14, 1 $70^{-1}$, discusses briefly the methodological problem of comparison. I agree with him in preferring to start with the analysis of the preserved text, but his suspicion of comparative approaches is too peremptory.

${ }_{8}$ The allusion to ShS proposed by W. K. Simpson, $7 A O S 78(1958), 5^{-1}$, is made plausible by the use of a $s \underline{d m} . n . f$ form in the appropriate place, since that form does not occur elsewhere in the Late Egyptian text in question (as noted by W. Guglielmi, $W d O$ I 4 (1983), i 53 n.b; see also id., $S A K$ I I (1 984 ), 352-3). The suggestion of N.-C. Grimal, that the question 'Who brought you?' Who brought you?' in the stela of Piye is a citation from our text, is insufficiently founded (La stèle triomphale de Pi(rankh)y au Musée du Caire (Cairo, I 98 I ), 64 n. I 53; see also id., in J. Vercoutter (ed.), Livre du Centenaire, I88o-1980 (Cairo, I 980), 64 n. I 53). As in other cases, such a formulation is more likely to derive from a common stock of phraseology than from a particular written text. Even if this point is disregarded, the range of Egyptian written literary texts is so incompletely known that a catalogue of citations will almost inevitably be misleading.
} 


\section{Folk analogies: frame and extended significance}

'The Shipwrecked Sailor appears more 'oral' in style than most Middle Egyptian literary texts. All preserved Egyptian literature was, however, produced for the small literate élite and should be evaluated within the literate context. ${ }^{9}$ It is hard to imagine written copies or written works having a role in the wider culture of the non-literate. This does not mean that the motifs of those works would have been unknown among those without access to writing, but that written texts will not have been the means of communicating them. Thus, although the New Kingdom story of Horus and Seth appears a less élite composition than Middle Kingdom literary works, Gardiner's depiction of it as 'intended for purely popular consumption' does not correspond to a plausible social reality. His picture of its reception at a 'recital by a village story-teller before a squatting circle of guffawing fellaheen' is unlikely. ${ }^{10}$ The shape and content of oral tradition are unknown, but the ubiquity of metre ${ }^{11}$ is probably related to its use in formal or elevated oral discourse, which should logically have precedence over writing as a context for such a device. Metre could be common to high culture and more general oral practice, and there is every reason to expect that story-telling occurred in both contexts. Continuous written texts will use oral practice as their precedent, but their forms in writing, and in particular their compression, set them far apart from original oral compositions, so that they provide little evidence for oral forms.

The Shipwrecked Sailor should not be considered as earlier than other Middle Egyptian literary texts on the ground that it appears more oral, since this would be to misinterpret its position in relation to the written and the oral. ${ }^{12}$ Its 'oral' quality is significant not so much in connection with oral narrative as with other literary texts. Many of its superficial features are markedly simple. Vocabulary and style are plain, while the structure, although elaborately layered, presents a straightforward narrative line, and a whole passage is repeated with only minor variations $\left(23-40=89^{-1} \mathrm{I} 0\right)$. The next preserved work with such ostensibly 'naive' traits is P. Westcar, which was probably composed in its present form more than a century later. ${ }^{13}$ Thus, the Shipwrecked Sailor aims at a surface simplicity and plainness as much as other Middle Egyptian 'classics' aim at complexity and richness of expression. Its style and tone contrast more strongly with those of contemporaneous texts than is the case with New Kingdom and slightly later stories, most of which are strongly formulaic; there, the exceptional text is Wenamun. ${ }^{14}$ Because of the Shipwrecked Sailor's complex implications and allusions to

\footnotetext{
${ }^{9}$ For estimated size of élite see J. Baines and C. J. Eyre, GM 6 I (1983), 65-72; for the context of ShS, compare the comment of Miriam Lichtheim that the text probably comes from the educated scribes and ... the ambience of the court' (Ancient Egyptian Literature, 1 (Berkeley etc., I 973), 2 I I).

${ }^{10}$ The Library of A. Chester Beatty: Description of a Hieratic Papyrus (London, I 931), I $0-1$ I.

${ }^{11}$ Summary G. Fecht, $L \ddot{A}$ iv, I I $27^{-54}$. The very different analyses of Foster agree here. For the metrical analysis of ShS see also n. I above.

${ }^{12}$ There is a general consensus that ShS dates to the Middle Kingdom. Simpson, $L \ddot{A}$ v, 6 I g, suggests 'Dyn. I I or early Dyn. I 2'. Apart from other considerations, the lack of other literary works datable to the Eleventh Dynasty makes the earlier alternative unlikely.

${ }^{13}$ Translation e.g. Lichtheim, Literature, I, $215-22$; new text: A. M. Blackman, ed. W. V. Davies, The Story of King Kheops and the Magicians (Reading, I 988 ). The $\mathrm{ms}$ is normally dated to the Second Intermediate Period, while its advanced form of Middle Egyptian favours composition after the other main Middle Kingdom literary texts. My allowance of a century's gap between ShS and P. Westcar is therefore conservative. See also next note.

${ }^{14}$ For interpretation, see A. Loprieno, Topos und Mimesis (Wiesbaden, 1988), 64-72, esp. 64 n. I 4 .
} 
topics that may have been esoteric in the Middle Kingdom, its superficial simplicity can hardly be due to direct derivation from oral folk narrative. In a more plausible socially exclusive oral context, the simplicity would probably be studied; even there, the allusions are likely to have been esoteric for many. Although several features of style and the frequency of repetition may seem close to oral form, the composition as a whole is probably not similar to orally created texts. Rather, the presentation imitates oral form, not least through being organized in three levels of story within story, but adds a dimension of dense allusion and compression instead of the stylistic richness of other texts. The story's status as written literature, as against a papyrus that records an oral composition, is demonstrated by textual corruptions that must have a written origin. ${ }^{15}$ It is in any case unlikely that a single recording of an otherwise oral composition should happen to be preserved. ${ }^{16}$

The 'oral' context is thrown into relief by the text's first words, $d d j$ jn, which probably read 'Speech by the worthy companion', rather than 'Then the worthy companion spoke'. This is not a full syntactic form, but a notation characteristic of written contexts. Although it is not identical with regular written introductions to speeches (normally $d d m d w$, whose associations were perhaps too solemn for use here), it seems to announce that the text is a written composition whose subject is a speech. If the text is then performed orally, as it surely would have been, it acquires an additional formal distancing device.

Thus, the presentation creates a form that the audience to a performance will recognize as imitating an orally-composed folk story, and this context affects and comments on the content. In considering aspects of this oral or folk analogy, my aim is not to make a motif analysis of the text on the lines of folklore studies, but to view its ostensible folk aspects from within its literary context; in this perspective, extended cross-cultural comparisons are irrelevant, however valuable they may otherwise be.

A feature typical of folk stories is that none of the participants is named. ${ }^{17}$ The only references to specific places are in the frame, where Wawat and Biga are mentioned $\left(9^{-} \mathrm{I}\right)$, and in the first sentence of the main story, which seems to allude to Sinai $\left(23^{-} 4\right.$, repeated $89-90) .{ }^{18}$ The characters are known by their titles, $h s t j-r j$ and $s m s w,{ }^{19}$ not even by a precise designation of role, and the king is mentioned in the frame and the narrative, but is not named. Nor is the snake named. This anonymity may have a broader, quasimythical significance.

The motif of the bystander (as the šmsw/narrator may be characterized), who butts in and monopolizes attention with his own story, probably has a folklore origin as a pretext for a narrative; within the text, it creates tension by implying that what is at stake is not in the narrative but in the context. ${ }^{20}$ It might also allow an elaboration into a cycle of stories,

\footnotetext{
${ }^{15}$ The best example is the phrase $j n-h t h h . n . j-s\langle w\rangle\left(3^{6-7}, 105^{-6}\right)$, which occurs twice but is not meaningful as it stands. Cf. Lichtheim, Literature, I, $212,215 \mathrm{n}$. I.

it The provenance of the papyrus is unknown, cf. Golénischeff, Les papyrus hiératiques, $\mathrm{I}$, but the excellent state of preservation suggests that it comes from a collection deposited in a tomb.

${ }^{17}$ Noted, e.g., by Simpson, $L \ddot{A}$ v, 6 I 9 .

${ }^{18}$ See e.g. J. Cerný, in A. H. Gardiner et al., The Inscriptions of Sinai ${ }^{2}$ (London, 1955), I-3; R. Giveon, $L A \ddot{v}$, 948.

${ }^{19}$ At the beginning of Sinuhe, the protagonist's principal title preceding his name is $\check{s} m s w(\mathrm{R} 2)$. The context is different because Sinuhe is the servant of the king, but the coincidence may be significant.

${ }^{20}$ The obvious English parallel is Coleridge, The Ancient Mariner, an elaborate imitation of a moral folktale; but there the context is no more than a pretext.
} 
and the Shipwrecked Sailor could possibly derive from a cycle or imitate one; the setting leaves space for a cycle, because the leader would not give the account of himself for which the narrator offers moral support until he reached the capital, many days' journey north of the frontier. Cycles or cycle contexts are common both in Egyptian literature and in folk stories. ${ }^{21}$ The central content of the snake's narrative, however, seems inappropriate to a cycle, so that allusion to cycle form is more likely than derivation from a cycle.

The bystander, as a 'sailor', belongs to a group known in many societies for telling tall stories: to place the narrative in such a person's mouth is to say that it need not be taken at face value. ${ }^{22}$ The same point is exploited by Hardjedef in P. Westcar, when he says that the stories preceding his own episode relate to former periods and what is true in them cannot be distinguished from what is invented. ${ }^{23}$ In that case, the result is to throw into relief, and thus to validate, the following narratives of the deeds of Djedi, and particularly of the birth of the three future kings. The effect of the choice of narrator on the Shipwrecked Sailor is less clear and may operate on more than one level. Since the central content is so serious that it is not formulated openly, it would not make sense for it to be devalued through the person of the narrator. It is more likely that the text is made into a tall story - which it is on any literal level-and told by an implausible narrator in order to shield that content. ${ }^{24}$ The narrator himself may allude to his ambiguous status when he

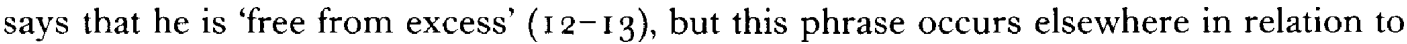
journeys and may be a regular attribute of a $\check{s} m s w w^{25}$ In view of the story that follows, it must, however, have ironical implications.

As noted especially by Bryan (n. 4 above), the narrator is far from being a 'hero'-a characteristic he shares with the protagonists of several other narratives. ${ }^{26}$ But the hapless traveller, who suffers disaster and does not know how to conduct himself in the situation in which he finds himself, could be a stock character from story-telling rather than a 'comical bad example', as Bryan proposes. His principal significance is as the vehicle of the narrative. This case is not sufficiently clear to show whether the text uses a folk analogy here or not. However this may be, Bryan must be right in assuming that the narrator is a 'type' or genre figure rather than a completely independent creation. His repeated mistakes and misunderstandings may derive from a known repertory of situations, and they have a value in moving the narrative forward. What separates the narrator from a character like Sinuhe (also a $\breve{s m s w, ~ n . ~ I g ~ a b o v e), ~ o r ~ t h e ~ p e a s a n t ~ i n ~ t h e ~ E l o q u e n t ~}$ Peasant, is that he appears to be all surface: there is nothing psychological in the transformations through which he passes, and this externality is mirrored by the flat narrative

\footnotetext{
${ }^{21}$ The suggestion of Simpson, $L \ddot{A} \mathrm{v}, 6 \mathrm{rg}$, that the papyrus may have been longer and subsequently cut just before the preserved beginning, is implausible, because a substantial blank leading edge is preserved and the writing starts at the top of a column; see Golénischeff, Les papyrus hiératiques, pl. I. The text should be treated as being complete as it stands.

22 This point is implied by Redford, 7SSEA 6, I $3^{-1} 4$. Compare an author's comment on the device of using an angler to tell stories because his 'veracity would be automatically suspect': P. G. Wodehouse, 'Preface', in id., The World of Mr. Mulliner (New York, 1974), [8].

${ }_{23}^{23}$ Broken: K. Sethe, Agyptische Lesestücke (Leipzig, I928), 28, 18-20; Blackman, The Story of King Kheops and the Magicians, $8,5^{-6}$.

${ }^{24}$ This presentation relates to the use of first person, see p. 69 below.

${ }^{25}$ Urk. vil, 62, 5; 66, 3. R. L. B. Moss, in Studies Presented to F. Ll. Griffith (London, I 932), pl. $48 b, 1.3$. A further example may be ibid. pl. $47 b, 1.9$, where the otherwise unknown word $h n w(W b$. III, I O4, Io) could be a miswriting of $h$ sw.

${ }^{2 h}$ See e.g. Baines, $\mathscr{F} E A 68$ ( 1982 ), 39.
} 
style. Any moral or didactic message is presented by the narrator only in his and the snake's rather sententious proverbial utterances. Ethical overtones in the narrative and in other features of the context are not realized through character. Here, too, the folk analogy creates a schematic feel to the text; but the context and elaboration of the schema become quite complex, while the first person narrative form precludes any simple identification with folk stories.

The use of stock motifs, situations and formulations is visible in the introduction to the two stories within the story. ${ }^{27}$ The $\check{s} m s w$ begins the last section of his introduction with a proverb, 'The mouth of a man saves him' $(\mathrm{I} 7-18)$, and starts the narrative itself with the formula 'Let me tell you the like thereof/which happened ...' $(2 \mathrm{I}-2)$, which is repeated word for word by the snake (I25). The narratives are made into 'proverbial' responses to situations and their explicitly stated nature as analogies for one another is emphasized by the formal parallelism. Contrasting with this framing is the snake's introduction to its narrative, which comes at the crucial centre point (I 24):

How fortunate is he who tells his (bitter) experience

$\langle$ after $\rangle$ the suffering has passed.

This statement, which is also proverbial, ${ }^{28}$ is at home in folk and other narrative because it provides a reassuring point of departure for story-telling by anticipating a 'happy end', or at least the protagonist's survival, but its purpose in the text is probably more profound. It comments both on the sailor's narrative and on the snake's, which follows at once, while making a statement that is valid within and outside the text. The statement also looks forward to the snake's moralizing about self-control and how it will assist the sailor to return home-which it will not do in any direct way-and to be reintegrated into society.

This moral contrasts with other implications of the narrative as a whole, which is framed by further proverbial, or at least stereotyped, statements. The narrator's summary to the expedition leader, 'The mouth of a man saves him', must be ironical in context because of the leader's complete silence-an irony of situation paralleled on a grand scale in the Eloquent Peasant. ${ }^{29}$ At the end, the narrator says ( $\left.180-2\right)$ :

See me after I reached land, after I saw what I experienced.

Listen, then, [to me]. To hear is good for a man. ${ }^{30}$

\footnotetext{
${ }^{27}$ On proverbs see B. Gunn, $\mathscr{H} E A$ I 2 ( ( 926$), 282-4 ; \mathrm{W}$. Guglielmi, $L \ddot{A}$ v, I 2 I9-22; F. Junge, $L \ddot{A}$ rv, $1041-3$.

${ }^{28} \mathrm{~A}$ close parallel is the protasis of an offering formula on a Middle Kingdom stela: 'inasmuch as you wish ... that you should arrive (?-ph) in peace, that you should recount your expeditions to your wives ...' (Sethe, Agyptische Lesestücke ${ }^{2}, 88,2 \mathrm{I}-2$ ). Since this is unlikely to apply well to many who might read the formula, it probably mobilizes a stock situation.

In Western literature there is a well-known opposite saying, which probably draws on a similar background in story-telling and has a similar narrative function, by Francesca da Rimini in Dante, Inferno, V:4.1. This is alluded to in the opening of Alfred de Vigny's Grandeur et servitude militaires (e.g. Paris and London, Collection Gallia, n.d.), 3, where in introducing a narrative of his tribulations in military service the author inverts it to make a statement very close to that of the snake.

${ }^{29}$ Text: R. Parkinson, The Tale of the Eloquent Peasant (Oxford, forthcoming); translation e.g. Lichtheim, Literature, I, I 69-84.

${ }^{30}$ Reconstruction uncertain. The lines could read 'Listen, then [to my speech]./To hear is good for a man'.
} 
This again is paradoxical, since all the leader has done is to act as a captive audience, but now he will at last speak, rather than hearing. The contrast between these two statements is made the stronger by their both being preceded by the phrase 'Listen to me' ( $12, I_{1} I_{-2}$ [uncertain, see last note]). 'Reaching land' can evoke death and burial, the ultimate mooring and landing, which the snake mentioned earlier ( 169 ). Similarly, 'experiencing' $(d p j)$ is a key word which takes up the introduction to the snake's narrative to make a formal pattern. There are parallels for these formulations in Sinuhe, ${ }^{31}$ but their significance may also be wider and less literary, lying in the recall of general categories and wisdom, which here describe a process and its end in relation both to real events and to the sequence of the narrative, so that their character is different from similar statements in instruction texts.

The last sentence of the text, spoken by the expedition leader $\left(185^{-6)}\right)^{32}$

Who gives water [to] a bird at dawn when it will be slaughtered in the morning?

is proverbial or aphoristic, but, unlike the other proverbs, its meaning is in its allusion and not directly in what it says. It could form an ironical summary of the text's meaning, or its function could relate more closely to the narrative and to the leader's undecided destiny. Spalinger and Devauchelle have enriched its meaning with parallels: the leader alludes to a practice of giving drink to a fowl before it is slaughtered, whose religious, or possibly instrumental, significance is unknown. This excludes the widespread older interpretation of 'who would give water ...' as meaning that such an action would be pointless. ${ }^{3.3}$ Instead, the leader is the bird and the answer to his proverbial question is 'the slaughterer'-the narrator, who gives the 'water' or the narrative. A possible reading of this situation, that the leader sees the narrator as condemning him for an even worse failure than his own on an expedition, is unlikely, because the leader's expedition has returned intact $(7-1 \mathrm{I})$, even though it has presumably not achieved its goal. The only consistent interpretation I can offer is that the leader is so sunk in despair as to assume that the narrator is attacking, rather than helping, him with his story. ${ }^{34}$

The use of proverbs is distinct from that of narrative formulae and extends the range of the allusions to 'folk' content, ${ }^{35}$ but the two devices may have a similar purpose. The morality of the proverbs should be taken seriously, but any reduction of the text to a

\footnotetext{
i1 The general metaphor of life as a journey on water underlies much of the interpretation of $\mathrm{H}$. Goedicke, Die Geschichte des Schiffbrüchigen (Wiesbaden, I 974), esp. p. 82. dpj 'experience' has a parallel where Sinuhe is near death from thirst and says 'this is the taste $(d p t)$ of death' (B 23). Landing comes at the end: (B 310$)$ : 'when the day of landing came'. (The 'mooring' of Ammunenshi's marrying his daughter to Sinuhe, B $78-9$, is probably irrelevant here.)

:2 See M. Gilula, in Studies in Honor of George R. Hughes (Chicago, I 976), 75-82; Spalinger, GM 73, 91-5; Devauchelle, $G M$ I I, 2 I-5 (Devauchelle's free reading 'does one not give water ...?' cannot be reconciled with the wording of the text, because the question is introduced by 'Who?').

$\therefore 3 \mathrm{E} . \mathrm{g}$. Kurth, $S A K$ I 4 , I $75-6$, I $78-9$, rightly rejecting Otto's optimistic reading of the sentence.

it The passage could allude to sacrifice, rather than the butchery of a bird. This could even imply that the leader would be discarded after sacrifice as something useless; cf. H. Junker, in O. Firchow (ed.), Agyptologische Studien [Fs Grapow] (Berlin, I 955), I 68-75.

${ }^{35}$ Guglielmi, $L \ddot{A} \mathrm{v}, \mathrm{1} 220^{-1}$, derives proverbs from the twin sources of instruction texts and 'folk' wisdom, whereas my argument assumes that their associations are essentially with the latter. This distinction may be a matter of literary formulation rather than of different social context, but I would prefer to view proverbs as not being distinctive of high culture.
} 
presentation of a rather trite moral message would not do justice to it. The proverbs retain their quality as oral wisdom. They occur both at important junctures and in a scattering throughout the text, and they represent almost mechanical encapsulations of a message. Such a usage is characteristic of oral discourse, oral narrative and other oral genres, ${ }^{36}$ and so in a written and high-cultural context places a bracket round what they assert. They state the meaning of the events as if in a folk story, and commented according to folk categories, rather than any absolute meaning. This relativization is countered to some extent by the generality of most of the proverbs' values, which would be good for almost any situation, but the point remains that the text presents both events and some moralizing commentary in a form that makes their validity more internal to its own discourse than general. ${ }^{37}$

While this relativization of the proverbs and their moralizing may not be critical, there is a similar and crucial relativization of the narrative as a whole. The text has been shown, principally by M.-T. Derchain-Urtel, ${ }^{38}$ to present in the snake a being who is the creator god, who has survived, perhaps with his daughter Maat, the catastrophe of the end of creation and the loss of the other gods, as symbolized by the seventy-four forms of the sun god. The island this being inhabits is an explicitly fictional location outside the cosmos, time and space; it exists only in the text and will disappear after the narrator's encounter with the snake. This interpretation does not exclude others. In an alternative outlined by W. K. Simpson: ${ }^{39}$

The text can be read in part as an astronomical metaphor; the serpent as the sun, a falling star ..., a stay of four months, a return journey of two months, and a ship which sinks beneath the waves with 120 men only to reappear (?) later.

This reading, and that of Kurth ${ }^{40}$ who sees the narrative as describing the daily solar cycle, agree with Goedicke (n.3 I above) in interpreting it allegorically. The difficulty here is that the allegory elucidates the narrative only 'in part'-which is not the case with the explicit allegory of 'Truth and Falsehood, whose plot forms a more consistent analogy for the myth of Osiris and Seth. ${ }^{41}$ Kurth's and Simpson's readings may add meaning to the narrator's experience by integrating it into other cosmic patterns, giving it both shortterm periodicity and the most extended spatial and temporal reference, but they do not exhaust the text's significance or supplant the less neat and more securely founded interpretation of Derchain-Urtel; it is also difficult to choose between them. If such an extra level of meaning is accepted, both the many-layered character of the narrative and its ostensible 'folk' features can remain integral to an interpretation. ${ }^{42}$

\footnotetext{
${ }^{36}$ See, e.g., W. J. Ong, Orality and Literacy (London, i 982), 33-6.

${ }^{37}$ Many further examples could exist. Thus, the expression 'who foretells (something) before it has come, who acts before it has happened (i.e. anticipates events: $s r n j j t j r j ~ n h p r t$ )' on a Middle Kingdom stela (P. A. A. Boeser, Beschreibung der aegyptischen Sammlung des Niederländischen Reichsmuseums in Leiden, II (The Hague, igo9), pl. 7, 4th col. on right) is related to the crew's qualities of 'foretelling a wind before it had come,/a storm before it had happened' $(3 \mathrm{I}-2,97-8)$, and may be a common turn of phrase.

${ }^{38} S A K$ i (1974), 83-104.

${ }^{39} L \ddot{A} \mathrm{v}, 620$.

${ }^{40} S A K{ }_{14}, 173-5$.

${ }^{41}$ E.g. M. Lichtheim, Ancient Egyptian Literature, II (Berkeley etc., I 976$), 2$ I I- 14.

${ }^{42}$ Kurth, $S A K$ I 4, I 7 I, makes a similar point as a principle of interpretation, but then seems to prefer a single reading.
} 
This central conception of the end of the cosmos and the rarefied knowledge of the seventy-four forms of the sun god are presented as if they were folklore. Other texts relating to the end of the cosmos, Coffin Texts Spell $1130^{43}$ and Book of the Dead Chapter $\mathrm{I} 75,{ }^{44}$ are preserved in relatively widely disseminated sources and are generally assumed to derive from separate literary compositions rather than being original mortuary texts, ${ }^{45}$ but the seventy-four forms of the sun god are known only from the Litany of Re, ${ }^{46}$ which is first attested from the New Kingdom, and then only in the most restricted contexts. Following Wente and Assmann, ${ }^{47}$ in particular, I assume that the Litany, like the underworld books, was composed in the Middle Kingdom like the Shipwrecked Sailor, although these texts were not recorded on the monuments before the New Kingdom. The list of seventy-four names, which is not a continuous exposition, could well be older than any Middle Kingdom written version, and hence could even be a piece of restricted knowledge from a time before there were continuous texts; I see no means of assessing this question. ${ }^{48}$ It follows from Wente's and Assmann's different interpretations that the original context of the underworld books was not the deceased king's destiny in the hereafter but either the regular solar cult (Assmann) or an aspect of it that involved the 'initiation' of individuals (Wente).

The Shipwrecked Sailor could allude to the belief in the seventy-four forms in the Litany (which is an enumeration rather than an exposition), or it could allude to the Litany itself. Whichever it does, the exclusivity of the belief remains: the story mobilizes a piece of restricted sacred knowledge in a non-sacred context. The same would probably apply to Simpson's 'astronomical metaphor' pattern. 'These pieces of restricted knowledge could hardly have been incorporated into the story without change or dissimulation, so that the indirect character of their use is integral to their presence. Apart from these changes, the 'folk' form may be what makes their use possible at all. The result

\footnotetext{
${ }^{4.3}$ CT vII, 46 I $c^{-} 47 \mathrm{I} g$. Translations e.g. Lichtheim, Literature, I, I $31-3 ;$ E. Otto, in J. Assmann et al. (eds.) Fragen an die altägyptische Literatur: Studien zum Gedenken an Eberhard Otto (Wiesbaden, 1977), I-I 8. The Book of the 'Two Ways, into which it was incorporated, has been discovered in sources from two sites other than el-Barsha (D. P. Silverman, 'Textual Criticism in the Coffin Texts', in Religion and Philosophy in Ancient Egypt (New Haven, 1989), 39-43, and thus was more widespread than had been thought. Spell I I 30 is usually considered to be alien in the Book-which itself was not originally a mortuary composition (see e.g. Oto, op. cit. 5-6) - and so could have been inserted from a different and more generally known context. However this may be, its spanning of genres probably increased its availability.

${ }^{4} \mathrm{E}$. A. W. Budge, The Chapters of Going forth by Day or the Theban recension of the Book of the Dead, III (London, I 910), 72-7. See e.g. E. Hornung, Das Totenbuch der Ägypter (Zurich and Munich, 1979), 365-71. The earliest study to relate this text to the Shipwrecked Sailor was G. Lanczkowski, Zeitschrift für Religionsund Geistesgeschichte, 5:3 (I953), 1-10. The occurrence of the crucial part of the speech of Atum in Coffin Texts Spell I 84 (CT III, $82 d-83 a=$ R. O. Faulkner, The Ancient Egyptian Coffin Texts, I (Warminster, I 973), 154 [misinterpreted]) establishes its relevance to the period of the Shipwrecked Sailor (see Lanczkowski, op. cit.; E. Otto, $C d E 37$ ( 1962$), 250$ ). It is impossible to know whether the preserved form of BD 175 goes back to the Middle Kingdom, but there is no strong indication that it does not; cf. Otto, in Fragen an die altägyptische Literatur, 5 with n, 12.

${ }^{\text {th }}$ E. Hornung, Das Buch der Anbetung des Re im Westen (Sonnenlitanei) (2 vols., Geneva, 1975-6).

${ }^{47}$ E. F. Wente, FNES 41 (I982), I6I-79; J. Assmann, Re und Amun (Fribourg and Göttingen, I983), 22-53. The authors' views differ, but they both assign the original context of the underworld books to the sphere of the living and not of the dead. The most extensive discussion is by Assmann, 'Tod und Initiation im altägyptischen 'Totenglauben', in H. P. Duerr (ed.), Sehnsucht nach dem Ursprung [Fs Mircea Eliade] (Frankfurt a.M., I 983), 336-59 (English translation in Religion and Philosophy [n.43 above], I 35-59); this is only peripherally concerned with esoteric texts.

${ }^{48}$ For another case where an early date can be made plausible see last note.
} 
is a delicate balance between display and concealment of esoteric material. This transposition is related to the pervasiveness of decorum in Egyptian cultural artefacts. ${ }^{49}$

So far, I have discussed relations between written styles of narrative and other presentation on the one hand and oral and folk styles on the other, but I have not related the narrative to actual folk stories and have relied on connections that have been established between the narrative and Egyptian religious conceptions. This approach is limited, because there are analogies between the plot and those of folk stories. As remarked by Kurth, ${ }^{50}$ comparisons with examples of travel, shipwreck, and so forth in other cultures and periods are vague, but they remain relevant, because they form part of the story's accommodation to folk models. There is a convergence between travel abroad as a motif in Egyptian narratives and in folk stories, but Sinuhe and Wenamun show that the theme is not limited to folk-style texts, so that it may have a wider meaning in the Shipwrecked Sailor. I suggest that this meaning is twofold, both making a folk allusion and incorporating a domain of potentiality absent from the immediate Egyptian world. This point is fairly clear in relation to the narrator's journey to the edge of the cosmos, and is part of the text's formal and thematic organization, in which the narrator's journey is both a literal movement and a progression in values and comprehension-which are presented to the audience rather than being assimilated by him (in Sinuhe the progression is more internal).

A final aspect of the folk analogy is its relation to moral or moralizing readings of the text. The harsh fates of the ship's crew and the snake's companions are typical of folk stories, in which the destruction of the wicked, or simply of figures that get in the way of the plot, is commonplace. Later in the text, both the narrator and the snake-after its initial grief-attend no more to the fate of their dead companions. Here, any subtle moral concerns may be irrelevant. Such a perspective can, however, do justice to only one of the text's levels.

One motif that probably relates to a known but deviant strand of wisdom, but is not a folk motif, is the snake's rejection of the offerings the narrator proposes to make to him, on the grounds that he already has in abundance all the items mentioned (149-52). As emphasized by E. Hornung, ${ }^{51}$ such a tension in ideas is fundamental to relations between gods and humanity; before people can offer to gods, the gods have everything. Nonetheless, the gods expect offerings and are well disposed if they receive them. The uselessness of offerings implied in the Shipwrecked Sailor can be compared with the attitudes of some harpists' songs, that there is no point in making provision for an unknowable future, in this case human death and the grave ${ }^{52}$ In turn, these notions are related to wider discourse about reputations and the past, ${ }^{53}$ with which the snake also contrasts

\footnotetext{
${ }^{41}$ The possibility of such a concealment was recognized by Otto, $Z \ddot{A} S 93,100-1$. For decorum see J. Baines, Fecundity Figures (Warminster and Chicago, 1985), 277-305.

${ }^{50} S A K$ I 4 , I 7 I.

${ }^{5}$ Conceptions of God in Ancient Egypt (Ithaca NY, I982), I97-205; see also, citing ShS, G. Fecht, ZÄS I 00 (1973), 16.

'Most recent edition: M. V. Fox, The Song of Songs and the Ancient Egyptian Love Songs (Madison and London, I 985), 378-80; see also id., Orientalia 46 (1 977), 393-423. General study: J. Assmann, in Fragen an die altagyptische Literatur, $55^{-84}$. The dating of the 'Harpist's song from the Tomb of King Inyotef' is uncertain; it could belong to the Middle Kingdom. The songs as a whole are known from the New Kingdom, but their context existed earlier, and the associated ideas may have existed too.

${ }_{53}$ Cf. J. Baines, in R. Layton (ed.), Who Needs the Past?(London, I 988), I 3 I-49.
} 
offerings $\left(\mathrm{I} 59^{-60}\right)$. The idea that offerings are useless is known from the Admonitions, ${ }^{54}$ but its significance is different there, being related first to personal magical and religious concerns and only secondarily to divine cult. The chief concern there seems to be that there is no contact between human and divine, and the gods do not hear and respond to human attention; this is the opposite of the context of the Shipwrecked Sailor, but in the story this issue is not central, because the myth it implies has a different focus. Doubt about the efficacy of human action toward gods is probably as widespread as gods. When the snake exploits this idea, the situation is ironical, for a god who does heed a man is telling that man that he need not heed the gods in a traditional way; he then even gives to the man almost exactly what the man had been planning to offer him. Because the idea that offerings may be ineffective is so general, it is difficult to relate it to a social or religious setting, but it is important that this was not a unique insight. At the same time, the snake's own story of suffering shows that there are limits to the efficacy of divine, as well as human, provision.

\section{Myth and morality}

Folklore supplies a frame, plot, and several other features for the text, but, on a conventional understanding that folk stories do not incorporate central religious beliefs and values whereas myth does incorporate them, the core idea of the end of the world and the survival of the creator as a snake is mythical rather than folkloric. The resulting text is not a myth, although mythical literary narratives seem to have existed during the Middle Kingdom. ${ }^{55}$ Instead, the mythical part is encapsulated within a folkloric frame and is present chiefly as an allusion and a very indirect short narrative. Such allusive use of mythical material is normal in Egyptian texts. One distinctive feature here is that the mythical content is given a moralizing slant by the snake's story and comments on it. More critically for the myth, the folk context subverts the veracity and plausibility of the narrative which conveys it (as discussed in the last section). It is unlikely that the myth is devalued by this treatment. The restricted knowledge it contains is, rather, protected in order to be presented where it would otherwise not occur.

It is an extension of normal Egyptological usage to describe the conception of the end of the cosmos, which refers to the future, as a myth, but this is appropriate, because it is given a narrative structure, is placed in the past within the story, and has a present meaning and relevance through the abrogation of space and time. ${ }^{56}$ The problematic

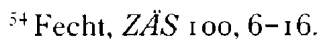

${ }^{53}$ The clearest-seeming example is the Horus and Seth fragment from Illahun, F. LI. Griffith. The Petrie Papyri: Hieratic Papyri from Kahun and Gurob (London, I 898), I, pl. 3, no. VI.1 2; II, 4. Assmann (GM 25 (1977), 33n.52), suggests that this narrative may have formed part of a magical spell (later parallel: C. Sturtewagen, $A S A E 69(\mathrm{I} 983), 24 \mathrm{I}-5)$. While this is possible, nothing in the text itself points in that direction. Some New Kingdom mythical narratives in magical contexts adhere to literary conventions and may have had a literary origin, and this could be the case here; see esp. Re and Isis: J. F. Borghouts, Ancient Egyptian Magical Texts (Leiden, 1978), no. 85 , pp. $5{ }^{1-5}$, with refs. p. I 22. The Herdsman's Story is also relevant here ( $n .6$ above). Whether $P$. Westcar recounts a 'myth' or not, it is in a different category from those texts; on the related birth cycle see J. Assmann, in id. et al., Funktionen und Leistungen des Mythos (Fribourg and Göttingen, I 982), I $3^{-61}$. See also next note.

${ }_{51}$ This leaves aside the question of when myth became a widespread form of religious discourse, which is relevant because the existence of narratives about the gods has been denied before a relatively late date; see Assmann, $G M$ 25, 7-42, building on Schott in particular. There has been no critique of these discussions,

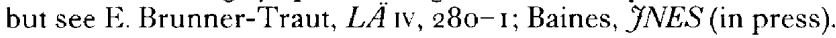


nature of such narratives can be seen in this instance, because the snake's short tale (1 26-32; ten metrical lines) is presented as a separate unit, followed by the moral derived from it, with little overlap between them; it appears almost like a short text incorporated in a larger one, although there is no reason to think that this is the case. Rather, this brief central passage acquires an extra focus by being 'detached' in this way.

This linking of the myth of the end of the cosmos with moralizing occurs in the Shipwrecked Sailor, CT I I30, and BD 175. In each, the moral gives either spiritual or domestic values more weight than fame, success, or wealth. The Coffin Text states that the human condition was created to promote equality and good conduct in the face of death-a conception probably related to the community of the living and the dead. ${ }^{57}$ In the following passage, which may derive from a separate source, ${ }^{58}$ this statement is relativized by the declaration that everything will end and start again, but the implications of this still broader context are there related only to the text's mortuary purpose. In $\mathrm{BD}$ 175 , the creator offers as blessings to Osiris, who is to survive after the end of the cosmos and with whom the deceased is identified, 'transfiguration in place of water, air and (sexual) gratification, and peace of heart in place of bread and beer ${ }^{59}$. In the Shipwrecked Sailor the moral is less clear. After the destruction of his 'companions', the snake seems to have achieved equanimity by mastering his grief. This is compared by implication with the loss of the ship's crew, but the snake's speech then looks forward to the narrator's return to the family, which is 'better than anything', a consummation that depends on 'controlling' his 'heart' $\left(\mathrm{I}^{2-4}\right)$. In this, he will neglect the role of the expedition leader for that of the normal individual-just as the values of C'T I I 30 are applied to any and all of humanity-but he does not then do so in the continuation of the text.

The moral the snake derives from its experience is the bleakest and most paradoxical element in the text. After the destruction of the other beings with whom one has lived, and of the cosmos, so the mythical reading would imply, all that is left is to display fortitude in the face of loss. If the snake is the creator, it is in some sense absolved of responsibility for the loss, which is left to a physical agency-a shooting star-rather than a volitional one. A reading in moral terms might seem forced because of the supra-moral and supra-personal character of these events, but it should be retained, since the snake presents it explicitly in this light, as, by implication, does the frame for the entire text. The issue of free will and divine knowledge is also implied by the snake's narrative and conditional foretelling of the future $\mathrm{e}^{60}$-although those abstract terms may over-assimilate the material to Western categories. The parallels of CT I I 30 and BD I 75 show a moralizing reading of a myth which seems to take it away from its natural context. CT I I 30 , too, absolves the creator for theodicy. Myths tend to be morally neutral or ambivalent and seldom have an explicit moral message, and this moralizing is one of the features that has led commentators to consider these texts as literary, rather than conventionally

\footnotetext{
${ }^{57}$ See n. 43 above. See also J. Assmann, Der König als Sonnenpriester (Glückstadt, 1970), 58-70; Baines, YEA 73 ( I 987), 80-1, 86-8.

${ }^{5 \times}$ Cf. Otto, in Fragen in die altägyptische Literatur, $15^{-1} 8$.

${ }^{59}$ This is the version of BD 175 : Budge, Chapters of Going Forth by Day, 111, 73, 1. 1 2; C7 III, 82d-8 $3 a$ reads: 'I have set transfiguration after(?) copulation, joy after desire $(?-j w t-j b)$, and peace of heart after eating bread'; see Otto, $C d E$ 37, 250-1. For $m$-znw 'after' see M. Gilula, $7 N E S$ 28 (i 969 ), i 22 . Here, this may mean that in a future life, 'after' this life, transfiguration etc. will replace the more basic satisfaction of desires and needs. See also n. 43 above.

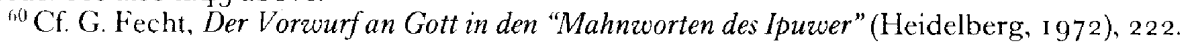


mortuary, and instrumental in purpose. Neither text has the formal characteristics of a mythical narrative.

This mythical context is part of the wider 'historical' predicament of society and cosmos. The ultimate fragility of Egyptian conceptions of social and world order may be compared with the notion that all will end, to which the snake gives such vivid expression, while certain features of the maintenance of order, such as the restriction of texts relating to the solar cult, parallel the evocation of esoteric knowledge, and especially the closely related seventy-four forms, in the story. ${ }^{61}$

A final 'mythical' element is the island. This is not itself a myth, but it probably relates to conceptions like the ideal agricultural existence of the Fields of Ealu, which are attested from the Pyramid Texts on, and most characteristically in the vignette to BD 1 I $0 .{ }^{62}$ The specific point of comparison here is that the island turns out to be cultivated $\left(47^{-} 5^{2}\right)$. Any evocation of the Fields of Ealu must relate to a different domain from the 'eschatological' narrative of the destruction of the snakes, so that no general vision of the afterlife or last things is created; the island is also not depicted as mortuary. Its real existence within the narrative is rendered problematic by the statements of the snake that it is an island of the $k a^{\prime}$ ( $\left.\mathrm{I}_{\mathrm{I}} 4\right)$ and that the narrator 'will never (or did never?) see this island, which emerged from (or will become?) the waves' ( $153-4$; translation uncertain). Thus, something integral to Egyptian beliefs about the afterlife, and mythical rather than folkloric, may be transformed into the model for a fictitious, morally paradigmatic element in the story. Such a treatment would be inappropriate in anything but a literary fiction.

This need not exhaust the island's meaning or associations, because it could also be related to the primeval hill or first created matter; ${ }^{63}$ whether this reading is apt depends in part on the rendering of the problematic ll. $153^{-4}$ (see above) ${ }^{64}$ In the cyclical view of CT I I 30 , the place of the end of things could also be that of their beginning; the cultivated character of the island does, however, speak against a strong connection here.

\section{Form}

Like Sinuhe, the Shipwrecked Sailor has an internally cyclical form, in this case A B C D $\mathrm{C}^{\prime} \mathrm{B}^{\prime} \mathrm{A}^{\prime}$, where $\mathrm{A}, \mathrm{A}^{\prime}$ is the frame of the ${ }^{\prime} m s w$ and leader, $\mathrm{B}, \mathrm{B}^{\prime}$ the narrator's departure and return, $C, \mathrm{C}^{\prime}$ his life on the island, and $\mathrm{D}$ the central narrative of the snake. ${ }^{65}$ In $\mathrm{A}, \mathrm{A}^{\prime}$, narrator and leader occupy normal roles of the Egyptian élite, while $C, C^{\prime}$ is a paradisal analogy for human life, in which the divine can also be experienced.

A linear reading through the breaks in continuity creates difficulties, among which is the contradiction between the domestic ideal of the snake's presentation and the social integration and success of $\mathrm{B}$, in which the narrator starts as an expedition leader, like the leader he is addressing; in $\mathrm{B}^{\prime}$ he receives rewards for a successful homecoming. ${ }^{66}$ Thus,

\footnotetext{
${ }^{61}$ See Assmann, Re und Amun, 22-53. On pessimism, see also id., in D. Hellholm (ed.), Apocalypticism in the Mediterranean World and the Near East (Tübingen, I 983), esp. $352-7$.

${ }^{2} 2$ For the Fields of Ealu see e.g. J. Leclant, $L A$ I, I I $56-60$; for the vignette see Hornung, Totenbuch, $216-18$.

${ }^{63}$ For the topography of the world of creation, see R. B. Finnestad, Image of the World and Symbol of the Creator (Wiesbaden, I985), 42-51.

${ }_{64}^{64}$ Yet other islands, such as the Island of Fire of mortuary texts (R. Grieshammer, $L \ddot{A}$ II, 258-9), might possibly be brought into relation with the story.

${ }^{65}$ Compare the diagram of Kurth, $S A K$ i 4 , I 76 fig. I.

th Noted by Bryan, Sarapis 5, 8-9. I do not accept her view that the narrator presents himself as a member of the crew.
} 
as when Sinuhe is recalled to Egypt, his possession of a wife and family in Palestine becomes irrelevant, so the apparently modest ideals of the snake, with their paradisal island analogy, become irrelevant in the context of the elite member's integration and ambitions, as expressed in his promotion on return to Egypt. ${ }^{67}$ The text should not be pressed too far here, because nothing says that the narrator did not rejoin his family; this is not a contradiction but a matter of focus. In narrative terms, this shift also relates the narrator's story more closely to his message for the leader, who needs to present his expedition to the king: this progressive departure from and return to the 'plot' has structural advantages. The fate of the drowned sailors may similarly be irrelevant to the rest of the text.

A more difficult feature of this structure is that the snake god's request to the narrator, to 'place his good name (reputation) in your town' $\left(159^{-60}\right)$ when he gets back to Egypt, is not mentioned when the return takes place. The action could go without saying-since the snake asks for it to be done, it is done-but it is a little paradoxical, because neither the snake nor any other character is named. This anonymity is paralleled in CT I 130.68 Another narrative analogy is with the 'true' name of Re, which Isis succeeds in extracting from him in the story of Re and Isis, but the audience never learns it ( $\mathrm{n} .55$ above). The point of the story and of its incorporation in magical spells would be lost if it were revealed; similarly, if the snake were named, it would lose much of its aura, and would no longer be unknown ( 148 ) to people. More generally, the restricted knowledge exploited in the text requires that much be alluded to rather than named; in a different sense, this is a widespread feature of the use of myth in Egyptian texts ( $n .56$ above).

In two places the text seems to conceal identities by means of partly structural devices. In the first, the snake says to the narrator that '(the) god' has caused him to live and brought him to the island (I I 3 ). Since the snake is a god and subsequently completes the rescue, the 'god' could be himself; his third-person allusion to himself is then a concealment. ${ }^{69}$ Alternatively, the 'god' could be the generalized deity common in instruction texts and it would be difficult to say which god might be meant, apart from a notion that delivery from a catastrophe would be due to a divine agency which would not need to be specified ${ }^{70}$ The former of these readings is the more economical and probably to be preferred. The second mystification comes at the end, where the frame refers to the narrator in the first person: 'Then he (the leader) said to me (the narrator)' (183), apparently blurring the distinction between the levels of the story (in the schema above, this section is $\left.A^{\prime}\right) .{ }^{71}$ This detail can hardly be an error of first person for third, because use of the third person would here require a naming of the šmsz by title, rather than a pronoun. Either it can be taken as a more complex corruption of the text, which is possible, or it must be interpreted as it stands. In the latter case, there could be an extra level to the structure, so that the narrator's story included his interlocutor's response in a way that was not revealed until the end. The introduction in the first line of the story

\footnotetext{
${ }^{67}$ For Sinuhe, see Baines, $\mathscr{7 E A} 68$ (1982), esp. 43 for a similar argument on the irrelevance of Sinuhe's personal religious practice.

${ }^{68}$ See Otto, in Fragen an die altägyptische Literatur, 6. On names and anonymity of gods, see E. BrunnerTraut, $L A \ddot{A}$ I, 28I-9I; H. Brunner, in H. von Stietencron (ed.), Der Name Gottes (Düsseldorf, 1975), 33-49.

${ }^{61)}$ See Otto, ZAS 93, I 07-8; Bryan, Sarapis 5, 8.

${ }^{70}$ On the unnamed deity in instruction texts, see Hornung, Conceptions of God, 49-6o.

${ }^{71} \mathrm{On}$ interrelations between frame and main narrative, see L. Koenen, Bulletin of the American Society of Papyrologists, $22(1985)$, 191-2 with n. I 7 .
} 
would then be the only element that gave a neutral setting. Such a structure would also be an artifice, seemingly implying a position in a cycle. This detail is another indication of complexity of levels.

The most salient formal characteristic of the main narrative is that it in the first person. Several other literary narratives are told in this way, ${ }^{72}$ but they are not closely comparable with the Shipwrecked Sailor. The slight but significant third-person frame hardly affects the audience's immersion in the first-person narrative, although this impression could be different if the text were part of a cycle, perhaps consisting of firstperson narratives. First person is not a normal form for narratives of myths or folk stories, so that its literary use to present the former through the latter creates an initial irony and suspension of belief. The same general point probably applies to another Middle Egyptian narrative in which a human being meets a deity, the Herdsman's Story (n. 6 above). There, the paradox of the literary first person (singular and plural) is particularly strong, because the text incorporates a non-literary magical spell. ${ }^{73}$

Another analogy for first person is the speech of a deity or aretalogy. ${ }^{74}$ This may be significant, both because related forms occur in more narrowly literary texts such as Admonitions, ${ }^{75}$ and because the thematically relevant CT II 30 is such a speech. ${ }^{76}$ The snake's narrative can be compared with the latter, from which it differs in presenting its topic in a pure, uncommented form; while the spell exhibits narrative features, it has a didactic and thematic organization.

Thus, the use of first person has contrasting implications in relation to the text's general structure. It demonstrates that what might otherwise be considered a folk story (the text could not be mistaken for a 'true' narrative of a myth) is something else, while it allies the core speech of the snake with the most privileged and serious, but still artificial, form of divine discourse. ${ }^{77}$ At the same time, the personal form has small-scale effects on how the narrator is presented, allowing irony and indirection that would be evident to the audience. There is a contrast in implication, which is common to many narratives, between the untrustworthy narrator and the quality of testimony in a first-person narrative about an awe-inspiring experience. ${ }^{78}$

The first-person form is not used to any great extent for the oblique treatment of character (p. 59 above). Its potential here is clearest at the beginning, where the silent 'interlocutor' is a foil for the garrulous speaker and subsequent narrator. Later, the narrator progressively discovers, but does not state explicitly, that the island is cultivated

${ }^{72}$ See Baines, $Y E A 68,35$. The list could be extended.

${ }^{73}$ See M. Gilula, $G M 29$ ( 1978 ), 2 I-2; the text is $C T$ vil, $36 m-r=$ Herdsman's Story (n. 6 above), I $7-22$. See also J. R. Ogdon, GM 100 (1987), 73-80. Ogdon's suggestion that the Coffin Text borrows from the story has no clear foundation.

${ }^{74}$ See especially J. Assmann, $L \ddot{A}_{1}, 425^{-} 34$. The first line of the text can be related to this point, see p. 68 above.

${ }^{75}$ See e.g. Fecht, Der Vorwurf an Gott, $120^{-} 36$.

${ }^{76} \mathrm{BD}$ I 75 , whose core passage is a dialogue, uses a similar presentation.

${ }_{77}$ This has an original context in first-person divine speeches in temple relief, which are the earliest preserved continuous texts; cf. J. Baines, in id. et al. (eds.), Pyramid Studies and Other Essays Presented to I. E. S. Edwards (London, I 988), I 3 I. I would retain the past, and so partly 'narrative', reading of these speeches, against P. Vernus, in S. Israelit-Groll (ed.), Pharaonic Egypt, the Bible and Christianity (Jerusalem, I 985), $307-16$.

${ }^{78}$ The parallel with a theophany drawn by Hornung, Conceptions of God, I $28-35$, is valid in literary terms, but I doubt whether it shows what the Egyptians considered to be a true theophany; see my Fecundity Figures, I 43-4. 
$\left(47-5^{2}\right)$, so that it belongs to the domain of culture rather than nature, as well as having paradisal associations. This uncommented revelation is probably made more effective by first-person narration, which conveys the discovery economically.

\section{Didactic aspects and organizing motif}

Bryan's discussion ${ }^{79}$ centres on the narrator's character, which she relates to ideals of behaviour enjoined in instruction texts, against many of which he offends. Her parallels are valuable in illustrating the homogeneity of Egyptian literary phraseology, but her conclusions are problematic, because the narrator's predicament cannot be compared with the formalized social contexts of the instruction texts, while the folk analogy militates against taking the phraseology as representational of itself-that is, the analogy does not suit a conventionally didactic text. There is a distinction here between frame and narrative; in the frame, the phraseology may be well fitted to its ostensible purpose. The first few sentences ( I-I I) look to the different language of royal or non-royal inscriptions about campaigns abroad, ${ }^{80}$ and provide an apt context for the rest of the narrative. After them comes the direct, moralizing address to the leader which creates the motivation for the specific story told (12-r9). This contains the closest parallels for conventional moralizing and contrasts with the narrator's actions in the story, but the significance of this opposition lies in its relativization and mobilization of the context and of the following narrative, rather than in a moralizing commentary on its teller's actions. By contrast, the snake's moralizing $\left(1_{32-4}\right)$ uses phraseology similar to didactic texts and epithets of praise in biographies, but its exotic position must mark it as distinct from normal utterances of such sentiments, which are in themselves unremarkable: the values are striking because of their paradoxical placing. Only through integration with the text's total statement could they be generalized, so that it is difficult to say what they signify.

The narrator's presentation of himself and his ineptness before the snake may be both ironical and didactic. His initial exhortation on how to behave before the king favours this view, because his behaviour before the snake is almost the opposite of what he recommends ${ }^{81}$-although he does succeed in replying, which is more than Sinuhe does in a similar predicament before the king ( $\mathrm{B} 25^{2-6}$ ). A reading of this irony is that it shows that, despite a failed mission and initial inability to cope with a new situation, one may return and 'reach land' successfully; the injunction to 'see me' at the end would encapsulate this idea. The failure is not stated in as many words, but could be understood by the leader, or by the audience. This reading implies that there is both self-conscious irony of the narrator and irony addressed to the audience. On such an interpretation, both the text's 'teaching' and its literary framing are relativized in various ways. The 'teaching' remains internal to the text rather than general and should not be seen as giving the whole a primarily didactic purpose.

There is another sense in which an apparently moral or didactic notion can form an organizing principle whose meaning may not be only didactic. If the text's literary state-

\footnotetext{
${ }^{79}$ Sarapis $5 \cdot 3^{-1} 3$.

${ }^{80} \mathrm{Cf}$. J. Baines, in G. Dreyer and J. Osing (eds.), Form und Mass ... Festschrift für Gerhard Fecht (Wiesbaden, I 987$), 43-6$ I.

${ }^{81}$ Bryan, Sarapis 5, 3-13. Her further discussion, however, seems to assume that the narrator's irony is unconscious. 'This may be true in part, but it is difficult to accept as a whole, because he reports episodes like the snake's laughing at him (149), which he would hardly do if he were not aware of the bad figure he cut.
} 
ment is summarized, it can be said to be about confronting, accepting and making the best of adverse experience, and, in the narrative context, about presenting it to others so that it may have worth. Verbal associations of the terms show that this experience, or 'taste', is bitter or adverse. There is a further, ultimate sense in which such experience has meaning, since it leads to death and the passage into the next life and, so the snake's moralizing would imply, creates a cosmically transcendent principle which at the same time refers values back to the simplest and most domestic. At the end, the blandness and apparent optimism with which the narrator presents his 'reaching land' is gainsaid by the phrase itself; dying, for which it is a euphemism, is always ambivalent, whatever one's hopes. Death may not be the primary reference here, but it must be an association.

The focus on adverse experience also has implications for the narrator's presentation of events and the leader's final comment. The narrator begins by saying that the expedition from which they are returning has been successful, at least in returning to Egypt intact, but he then implies that its aims have not been achieved. However the leader's response is interpreted, he does not believe the expedition has been a success. Thus, the 'pessimism', which according to Kurth needs explanation as a distinctive feature, ${ }^{82}$ is integral to the text's organization and themes. There could be an irony in the leader's not accepting the optimism that experience can be turned to good effect, but he may be countering implicitly that the catastrophe is yet to happen. As an 'audience', he can be related to the wider audience of the text-which is not to say that his view should be adopted wholesale. ${ }^{8.3}$ His response can also be compared with the inserted stories in the Dispute of a Man with his $\mathrm{Ba}^{84}$ in giving an indirect, terse and hopeless illustration for an elaborate address. If the leader were to arrive at the king, all would probably be forgiven, but the point of the situation is that he has not arrived, and is thus open to starker alternatives. His predicament parallels that of the snake at the catastrophe, before it assimilated the lesson it teaches, and in this way it again mobilizes the esoteric knowledge on which the snake's central story is based.

The morality of experience is crucial in the introduction, in the snake's presentation of its narrative, and in the conclusion. Like many other features, it has an internal utility in motivating the narration, apart from any wider 'moral' significance it may possess. This organizing principle of experience is not necessarily didactic; it may have a more broadly aesthetic and literary meaning. Many major works of literature, including ones of great extent, are often regarded as having single organizing themes, such as ambition, revenge or destiny, but it does not follow that they can be reduced to moral statements about those themes. ${ }^{85}$

This line of argument stretches principles of interpretation, but may be useful in assimilating Egyptian works to wider literary types. Also, the text's comments on itself stress the centrality of experience. These should not be seen as absolutes, but as contextually significant orientations. In the situation of the 'traveller', experience and how it is mastered are crucial to ultimate destiny. By association, this travel may be the

${ }^{82} S A K{ }_{1} 4,{ }^{1} 75^{-9}$.

${ }^{83}$ Here, I give more weight to his position than does Kurth, $S A K$ I 4, I $76-9$.

${ }^{44}$ Cols. 56-85; e.g. Lichtheim, Literature, $1,165^{-6}$.

${ }^{85}$ An explicit, if remote analogy is Henry James's characterization of the theme of his The Portrait of $a$ Lady as a 'certain young woman affronting her destiny': 'Preface' to The Portrait of a Lady (New York, I go8 edition), xii. Compare the comment of Graham Greene on the motif's adequacy to sustain a narrative: 'Introduction' to The Portrait of a Lady (World's Classics, London etc., 1947), v-vi. 
journey of life itself, but the text's meaning does not reduce to that, any more than it can be abstracted from the élite milieu of the narrative and that milieu's phraseology.

\section{Conclusion}

This thematization of experience must be related to other aspects of the story. In some respects, the Shipwrecked Sailor contrasts here with a text such as Sinuhe, whose biographical structure militates against its being summarized in terms of a single theme. ${ }^{86}$ The notion of experience, which could apply to a work without supernatural overtones, may seem to sit awkwardly with the snake's esoteric narrative, just as the moral the snake draws is not necessarily the obvious one. But to insist on this discrepancy would be to use inappropriate unifying arguments. The text is diverse, but in a different way from Sinuhe, and its organization is on the two planes of human experience and cosmic event or myth. This full exploitation of myth in a text that does not recount a myth is alien to modern literary traditions. A further aspect that is so prominent as to form a distinct level of organization and meaning is the structure of story within story within story. The thrust of this is partly aesthetic, demonstrating a concern with form for its own sake, but it may also evoke the folk analogy by keeping the activity of story-telling to the fore throughout.

The Shipwrecked Sailor cannot be interpreted fully by any simple strategy or on any single interpretive assumption. I have used various approaches and have hardly asked whether these cohere to create a single meaning. In narrative terms, the text covers such a variety of events and such a span of space and time that loose ends are to be expected, particularly in a small compass; and works of fiction that tie up all their ends are seldom among the richest. The text's meaning may be ultimately single, but that meaning may not be analysable in any normal sense, being created rather in the assimilation of the brief whole. The unifying motif of how one masters experience does not seem close to the esoteric aspects, although those who were involved with concealed knowledge might not have agreed. There could be a tension between the lesson of experience and the esoteric knowledge at which the text hints, which would be achieved by access and by exclusion of others rather than by action or passion.

Despite its superficial plainness, the text is rich in allusion and association. ${ }^{87}$ Much of this allusion must be lost to the modern reader, and the identification of new elements could alter readings. I have not attempted a comprehensive analysis or a close verbal reading. The apparent denseness of allusion may, however, be in part an aspect of the story's being an alien cultural artefact, rather than being specific to this text, so that the salience of this feature is difficult to assess.

My strategy has been to interpret the text in terms of its assumed literary character, emphasizing the significance of the frame and assuming awareness of form in author and audience, as well as an exploitation of levels of oral and literary discourse. In pursuing literary meaning, this approach may go beyond what an ancient audience would have done-as well as falling short in other ways. Such an overstepping is part of literary interpretation and of integrating a work within widely applicable modes of analysis. The work's meaning can only be recovered by taking risks; the Shipwrecked Sailor is about, and rewards, risk and experience.

${ }^{8 t h}$ Cf. Baines, $7 E A 68$, esp. 33-8.

${ }^{87}$ Compare the comments of Otto, $Z \ddot{A} S 93$, I03. 